\title{
ON THE MODE OF ACTION OF HODYDAMYCIN
}

\author{
Ibrahim R. Shimi and Safwat Shoukry \\ Biochemistry Department, Faculty of Science, Ain Shams University \\ Cairo, E. A. R.
}

(Received for publication April 16, 1973)

\begin{abstract}
The present study was conducted to determine how hodydamycin inhibits microbial growth. Hodydamycin had no effect on either the cell membrane or the synthesis of the cell wall of susceptible organisms. The antibiotic inhibited protein synthesis through its scissating effect on DNA. No effect on the synthesis of RNA was observed.
\end{abstract}

The peptide antibiotic hodydamycin was first isolated by SHImI et al. ${ }^{1)}$ from the fermented broth of Streptomyces AS-Y-400. The antibiotic possesses substantial activities against grampositive bacteria, while its effect on most gram-negative organisms is minimal.

The present paper describes studies conducted on the mode of action of hodydamycin.

\section{Materials and Methods}

Organisms and culture conditions: Bacillus subtilis icc, Staphylococcus aureus (Oyama), and Klebsiella pneumoniae were grown in $200 \mathrm{ml}$ nutrient broth having the following composition $(\mathrm{g} / 100 \mathrm{ml})$ meat extract 0.15 , yeast extract 0.15 , peptone 0.5 and $\mathrm{NaCl} 0.5$ in shaking cultures $(220 \mathrm{rpm})$ at $35^{\circ} \mathrm{C}$ and harvested during the logarithmic phase at half maximal growth (optical density 1.0 at $660 \mathrm{~m} \mu$ ). The cells were collected by centrifugation at $15,000 \mathrm{~g}$ for 10 minutes and washed twice with sterile saline solution and were used for the following experiments.

Release of cellular material absorbing at $260 \mathrm{~m} \mu$ : The method applied was that described by MikıKo and YASUO ${ }^{2)}$. Intracellular substances from $S$. aureus were subjected to ultracentrifugation at $147,200 \mathrm{~g}$ using a MOM ultracentrifuge model 3170 for comparing the sedimentation pattern with non-treated cultures.

Preparation of protoplasts and spheroplasts: Washed cells of B. subtilis and S. aureus were suspended so as to attain a concentration of $0.08 \sim 0.1 \mathrm{mg}$ dry weight of cells $/ \mathrm{ml}$ in phosphate buffer ( $\mathrm{pH} 7.2$ ) containing $0.5 \mathrm{M}$ sucrose and $100 \mu \mathrm{g} / \mathrm{ml}$ of lysozyme. The suspensions were separately incubated for 90 minutes at $30^{\circ} \mathrm{C}$. The formation of protoplasts was confirmed microscopically. All preparations were then used immediately. Spheroplasts of $K$. pneumoniae were prepared according to the method of REPASKE. ${ }^{3)}$

Determination of the lysing properties on protoplasts and spheroplasts: The effect of hodydamycin was determined as follows: $2.7 \mathrm{ml}$ of a suspension of protoplasts (or spheroplasts in the case of $K$. pneumoniae) ( $c a .0 .08 \mathrm{mg}$ dry weight $/ \mathrm{ml}$ of the final solution, $2 \times 10^{8} \mathrm{cell} / \mathrm{ml}$ ), and $0.3 \mathrm{ml}$ of a solution containing hodydamycin were added to $0.5 \mathrm{M}$ sucrose solution to give a final volume of $6 \mathrm{ml}$. The mixture was incubated at $37^{\circ} \mathrm{C}$ and the absorbance at $660 \mathrm{~m} \mu$ was measured at 10-minute intervals for 40 minutes.

Determination of $\mathrm{N}$-acetyl aminosugars in the cell wall of $S$. aureus was carried out by the method of Strominger. ${ }^{4)}$ Total protein was assessed by the Folin reagent. ${ }^{5}$ ) The fractionation of DNA and RNA was carried out as described by SchmidT-THANNHAUSER. ${ }^{6)}$ RNA content of cells was determined by the orcinal method ${ }^{7)}$ and that of DNA by the indole method. ${ }^{8)}$

Degradation of DNA in intact cells of $S$. aureus: Washed cells were incubated with $\mathrm{C}^{14}$-thymine $(1.0 \mathrm{uci} / \mathrm{ml})$ containing medium for 2 hours, collected by centrifugation at $15,000 \mathrm{~g}$, 
washed with $300 \mathrm{ml}$ of tris minimum medium ${ }^{9}$ ) and flnally resuspended in the growth medium containing unlabeled thymine $(10 \mu \mathrm{g} / \mathrm{ml})$. One $\mathrm{ml}$ portions of the cell suspension $\left(\mathrm{ca} .1 \times 10^{8}\right.$ cells) (3,840 cpm in cold TCA-insoluble fraction) were supplemented with various concentrations of hodydamycin and then incubated at $37^{\circ} \mathrm{C}$. Samples of $0.1 \mathrm{ml}$ were withdrawn at different intervals and treated with $2 \mathrm{ml}$ of $5 \%$ cold TCA. The precipitates were washed twice with the cold TCA solution. The washings and supernatant after the TCA precipitation were admixed and then extracted with diethyl ether to remove the TCA. Radioactivity was assessed by a liquid scintillation spectrometer with a conventional toluene scintillation mixture.

Fig. 1. Effect of hodydamycin on growth and release of materials absorbing at $260 \mathrm{~m} \mu$ of test organisms

Microbial cells harvested at the logarithmic phase, washed with saline solution and then suspended in phosphate buffer of $\mathrm{pH} 7.2\left(\mathrm{ca} .1 \times 10^{8} \mathrm{cell} / \mathrm{ml}\right)$. Hodydamycin was supplemented to the cell suspensions and then latter incubated at $30^{\circ} \mathrm{C}$ for 70 minutes. Samples were withdrawn at intervals and the turbidity was assessed at $660 \mathrm{~m} \mu$ while the absorbance measurements at $260 \mathrm{~m} \mu$ was conducted for the supernatant after centrifuging the samples at $15,000 \mathrm{~g}$.
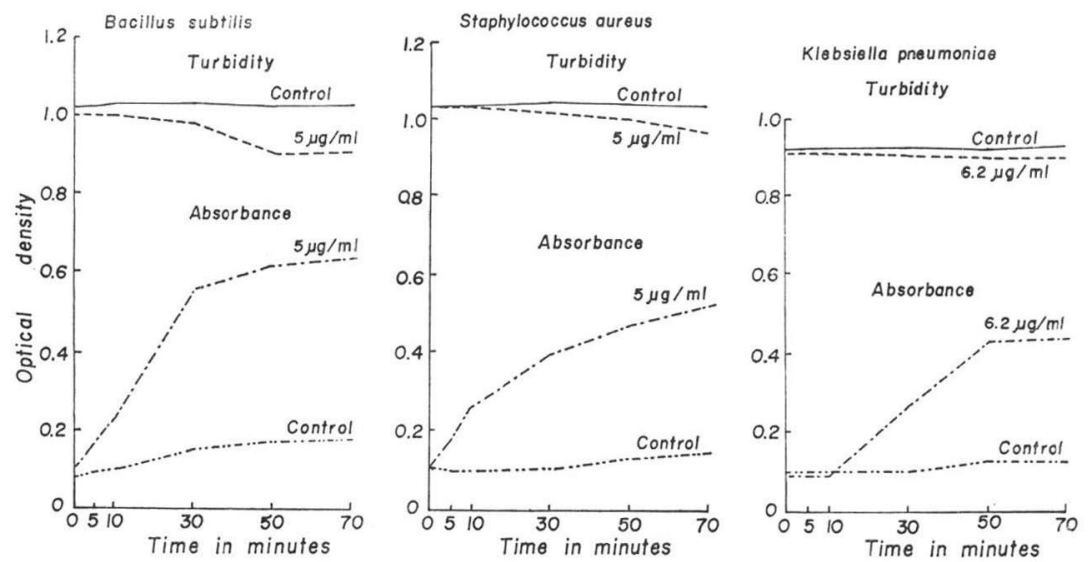

\section{Results}

Incubating the cells of $B$. subtilis, $S$. aureus and $K$. pneumoniae with hodydamycin at the MIC level (5.0, 5.0 and $6.2 \mu \mathrm{g} / \mathrm{ml}$ respectively) caused the release of $260 \mathrm{~m} \mu$-absorbing material (Fig. 1). The UV spectrum of these released materials (Fig. 2) is in accord with that of nucleic acids. The ultracentrifugal patterns of the substances released from $S$. aureus in presence and absence of the antibiotic are shown in Plates $1 \mathrm{a}, \mathrm{b}, \mathrm{c}$, and $\mathrm{d}$. The appearance of more than one peak (indicating compounds of different molecular weights) in treated cultures at this high field of gravity is probably due to unequal scission induced by hodydamycin on the DNA strands of the test organism.
Fig. 2. Absorbtion of released intracelluar substances induced by hodydamycin

A B. subtilis, B S. aureus, C K. pneumoniae

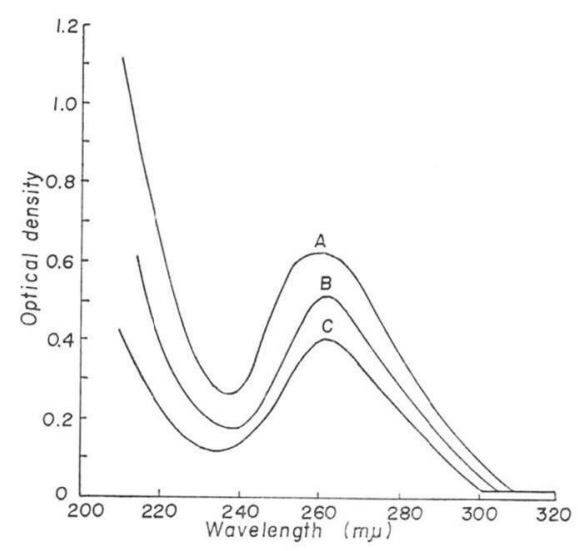


Plate 1. Sedimentation profile of the released materials from $S$. aureus cells

$\mathrm{a}$ and b: Sedimentation profile (SP) of control cultures (no hodydamycin) at 0.0 time (a) and after 20 minutes (b).

c and d: S.P. of cultures treated with the antibiotic $(5 \mu \mathrm{g} / \mathrm{ml})$ at 0.0 time (c) and after 20 minutes (d).

Photographs taken with Schlieren optics at $45,000 \mathrm{rpm}$ with the phase plate at angle $60^{\circ}$ and $20^{\circ} \mathrm{C}$
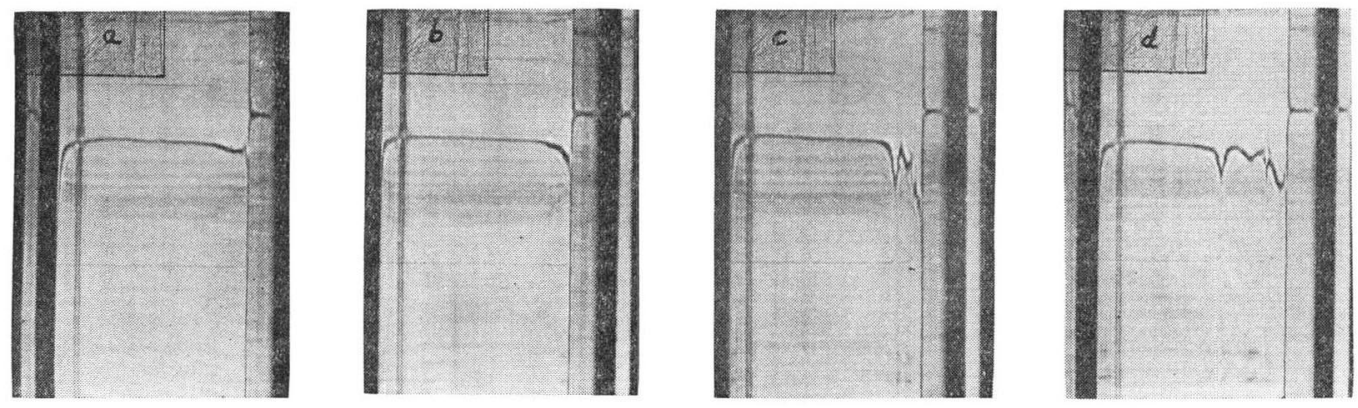

Fig. 3. Effect of hodydamycin on the protoplasts and spheroplasts of the test organisms
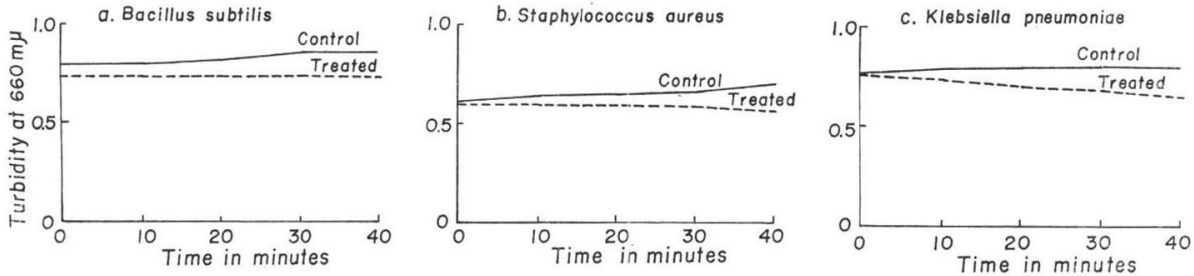

The results shown in Figs. $3 \mathrm{a}, \mathrm{b}$ and $\mathrm{c}$ demonstrate that the antibiotic at concentrations of 100 and $200 \mu \mathrm{g} / \mathrm{ml}$ failed to lyse sphaeroplasts and protoplasts respectively suspended in hypertonic solutions. This failure to lyse is presumably due to the antagonistic effect of the hypertonic solution.* Hodydamycin when added to cultures of $S$. aureus at the minimum inhibitory concentration of $5 \mu \mathrm{g} / \mathrm{ml}$ and at the higher concentration of $100 \mu \mathrm{g} / \mathrm{ml}$ did not induce accumulation of $\mathrm{N}$-acetyl aminosugars (Fig. 4).

The data presented in Fig. $5 \mathrm{c}$ indicate that hodydamycin inhibited protein synthesis in growing cultures of $S$. aureus when the antibiotic was added at a concentration of $5 \mu \mathrm{g} / \mathrm{ml}$. Increasing the concentration of hodydamycin to $10 \mu \mathrm{g} / \mathrm{ml}$ resulted in a more marked effect. On the other hand the lack of an effect of the antibiotic on the RNA content was noted (Fig. 5 a). Finally a marked decrease

* Guze, L.B.: Microbial Protoplasts, Sphaeroplasts and L-Forms. Williams \& Wilkins Co., Baltimore, 1968. page 309, lines $8 \sim 14$.
Fig. 4. Effects of hodydamycin and penicillin on the accumulation of $\mathrm{N}$-acetylglucosamine in cultures of $S$. aureus.

A Culture supplemented with $5 \mu \mathrm{g} / \mathrm{ml}$ of $\mathrm{Na}$ benzyl penicillin.

B Culture supplemented with $5 \mu \mathrm{g} / \mathrm{ml}$ of hodydamycin.

C Culture supplemented with $100 \mu \mathrm{g} / \mathrm{ml}$ of hodydamycin.

D Control culture (no antibiotic).

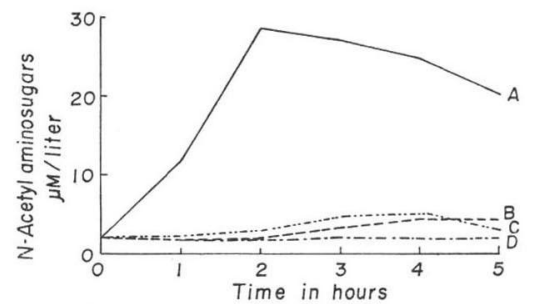


in the cellular DNA was observed (Fig. 5 b). In Table 1 the data show a notable elevation in the counts of cold $5 \%$ TCA-soluble fraction. This effect was markedly augmented by increasing concentrations of hodydamycin.

Fig. 5. Effect of hodydamycin on formation of DNA, RNA and protein in Staphylococcus aureus
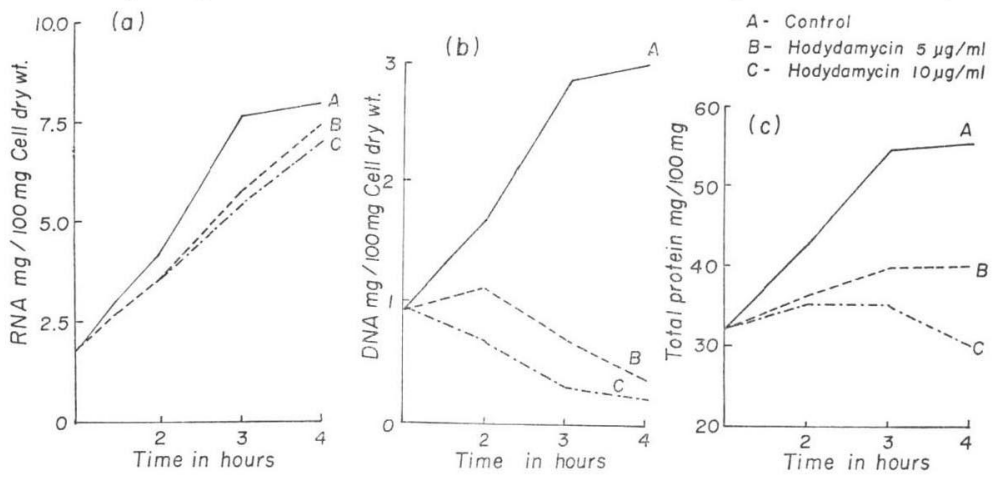

Table 1. Effect of hodydamycin on DNA breakdown in $S$. aureus

\begin{tabular}{|c|c|c|c|c|c|}
\hline \multirow{2}{*}{\multicolumn{2}{|c|}{$\begin{array}{l}\text { Concentration of hodydamycin } \\
\qquad(\mu \mathrm{g} / \mathrm{ml})\end{array}$}} & \multicolumn{4}{|c|}{ Radioactivity $(\mathrm{cpm} / \mathrm{ml})$} \\
\hline & & \multirow{2}{*}{$\begin{array}{r}5 \mathrm{~min} . \\
0 \\
3,830\end{array}$} & \multirow{2}{*}{$\begin{array}{r}20 \mathrm{~min} . \\
10 \\
3,829\end{array}$} & \multirow{2}{*}{$\begin{array}{r}40 \mathrm{~min} . \\
34 \\
3,783\end{array}$} & \multirow{2}{*}{$\begin{array}{r}60 \mathrm{~min} . \\
58 \\
3,755\end{array}$} \\
\hline 0 & $\begin{array}{l}\mathrm{S} \\
\mathrm{R}\end{array}$ & & & & \\
\hline 1 & $\begin{array}{l}\mathrm{S} \\
\mathrm{R}\end{array}$ & $\begin{array}{r}0 \\
3,832\end{array}$ & $\begin{array}{r}20 \\
3,802\end{array}$ & $\begin{array}{r}508 \\
3,302\end{array}$ & $\begin{array}{l}1,010 \\
2,800\end{array}$ \\
\hline 5 & $\begin{array}{l}\mathrm{S} \\
\mathrm{R}\end{array}$ & $\begin{array}{r}6 \\
3,825\end{array}$ & $\begin{array}{r}82 \\
3,755\end{array}$ & $\begin{array}{r}811 \\
3,025\end{array}$ & $\begin{array}{l}1,832 \\
2,000\end{array}$ \\
\hline 7.5 & $\begin{array}{l}\mathrm{S} \\
\mathrm{R}\end{array}$ & $\begin{array}{r}5 \\
3,827\end{array}$ & $\begin{array}{r}127 \\
3,713\end{array}$ & $\begin{array}{r}800 \\
3,010\end{array}$ & $\begin{array}{l}2,154 \\
1,676\end{array}$ \\
\hline 10 & $\begin{array}{l}\mathrm{S} \\
\mathrm{R}\end{array}$ & $\begin{array}{r}9 \\
3,823\end{array}$ & $\begin{array}{r}142 \\
3,696\end{array}$ & $\begin{array}{r}901 \\
2,905\end{array}$ & $\begin{array}{l}2,640 \\
1,204\end{array}$ \\
\hline 15 & $\begin{array}{l}\mathrm{S} \\
\mathrm{R}\end{array}$ & $\begin{array}{r}20 \\
3,782\end{array}$ & $\begin{array}{r}152 \\
3,675\end{array}$ & $\begin{array}{l}1,207 \\
2,610\end{array}$ & $\begin{array}{r}2,920 \\
912\end{array}$ \\
\hline
\end{tabular}

S : cpm of 5\% TCA-soluble fraction of harvested cells of $S$. aureus present in $1 \mathrm{ml}$ of culture.

$\mathrm{R}$ : $\mathrm{cpm}$ of $5 \% \mathrm{TCA}$-insoluble fraction of the same cells (residual).

\section{Discussion}

Hodydamycin had no effect on the cell membrane of sensitive organisms nor did it cause accumulation of $\mathrm{N}$-acetyl glucosamine in $S$. aureus cells.

The antibiotic inhibited the synthesis of protein in $S$. aureus and caused a marked decrease in the DNA content. This effect was markedly augmented by increasing concentrations of hodydamycin.

Ultracentrifugation of intracellular material from treated $S$. aureus cells revealed the presence of two main fractions S-30 and S-50 both lacking in the control cultures. This may be due to assymetric scission caused by the antibiotic on the DNA strands of $S$. aureus. This coupled with the observation that radioactivity present in the cold TCA-insoluble fraction was markedly 
reduced by treatment with hodydamycin confirms that the antibiotic caused scission of the DNA. These fragment so produced could exude from inside the cell resulting in a detectable increase in radioactivity in the supernatants.

One can therefore conclude that the primary effect of hodydamycin is scission of DNA, followed by reduction of protein synthesis.

The present results are similar to those effects observed by YAMAKI et al. ${ }^{10)}$ and ONO et al. ${ }^{11)}$ working with bleomycin and neocarzinostatin respectively.

\section{References}

1) Shimi, I. R.; A. Dewedar \& S. Shoukry: Hodydamycin, a new antibiotic. J. Antibiotics 23: 388 393, 1970

2) Iто, M. \& S. Koyama: Jolipeptin, a new peptide antibiotic. II. The mode of action of jolipeptin. J. Antibiotics 25: 309 514, 1972

3) Repaske, R. Lysis of gram-negative organisms and the role of versene. Biochem. Biophys. Acta 30: $225 \sim 232,1958$

4) Strominger, J. L.: Microbial uridine 5-pyrophasphate N-acetyl amino sugar compounds. J. Biol. Chem. 224: 509 516, 1957

5) Tolin, O. \& V. Ciocalteu: On tyrosine and tryptophane determinations in proteins. J. Biol. Chem. 198: 297 303, 1952

6) Schmidt, G. \& S.J. Thannhauser: A method for the determination of deoxyribonucleic acid, ribonucleic acid and phosphoproteins in animal tissue. J. Biol. Chem. 161: 83 89, 1945

7) Mejbaum, W.: Über die Bestimmung isleiner Pentosemengen insbesandere in Derivative der adenylsäure. Zts. Phyliol. Chem. 258: 117 120, 1939

8) Ceriotte, G.: A microbial determination of deoxyribonucleic acids. J. Biol. Chem. 198: 297 303, 1952

9) Fozchammez, J. \& N.O. KJeldgeard: Decay of messenger RNA in vivo in a mutant of Escherichia coli. 15. J. Mol. Biol. 24: 459 470, 1967

10) Yamaki, H.; H. Suzuki, K. NAGaI, N. Tanaka \& H. Umezawa: Effects of bleomycin $\mathbf{A}_{2}$ on deoxyribonuclease, DNA polymerase and ligase reactions. J. Antibiotics 24: 178 184, 1971

11) One, Y.; Y. WATANABE \& N. IshidA: Mode of action of neocarzinostatin: Inhibition of DNA synthesis and degradation of DNA in Sarcina lutea. Biochim. Biophys. Acta 119: 46 58, 1966 